Western University Scholarship@Western

Centre for the Study of International Economic

Centre for the Study of International Economic

Relations Working Papers

Relations

1984

\title{
Dual Exchange Rate Systems and Capital Controls: An Investigation
}

Charles Adams

Jeremy Greenwood

Follow this and additional works at: https://ir.lib.uwo.ca/economicscsier_wp

Part of the Economics Commons

Citation of this paper:

Adams, Charles, Jeremy Greenwood. "Dual Exchange Rate Systems and Capital Controls: An Investigation." Centre for the Study of International Economic Relations Working Papers, 8427C. London, ON: Department of Economics, University of Western Ontario (1984). 
ISSN $\quad 0028-4235$

ISBN $\quad 0-7714-0557-\mathrm{X}$

CENTRE FOR THE STUDY OF INTERNATIONAL ECONOMIC RELATIONS

WORKING PAPER $8427 \mathrm{C}$

DUAL EXCHANGE RATE SYSTEMS AND CAPITAL CONTROLS: AN INVESTIGATION

\author{
Charles Adams \\ and \\ Jeremy Greenwood
}

This paper contains preliminary findings from research work still in progress and should not be quoted without prior approval of the authors.

DEPARTMENT OF ECONOMICS THE UNIVERSITY OF WESTERN ONTARIO LONDON, CANADA N6A 5C 2

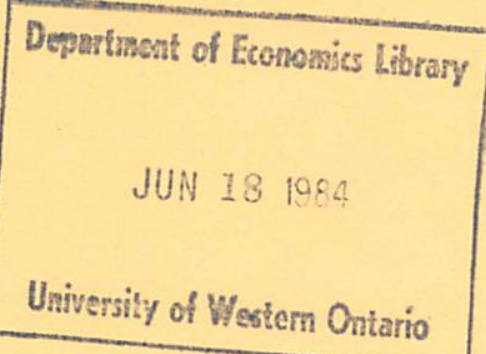


DUAL EXCHANGE RATE SYSTEMS AND CAPITAL CONTROLS: AN INVESTIGATION

\author{
by \\ Charles Adams \\ International Monetary Fund \\ and \\ Jeremy Greenwood \\ University of Western Ontario
}

June, 1983

Revised June, 1984

We would like to thank Peter Garber, Kent Kimbrough, Torsten Persson, and two anonymous referees for helpful comments. Any remaining errors are ours.

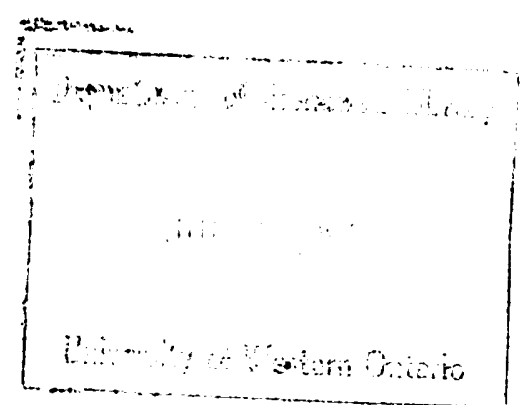


DUAL EXCHANGE RATE SYSTEMS AND CAPITAL CONTROLS: AN INVESTIGATION

\author{
by \\ Charles Adams \\ International Monetary Fund, Washington, DC 20431 \\ and \\ Jeremy Greenwood \\ University of Western Ontario, London, Canada, N6A $5 \mathrm{C} 2$
}

\begin{abstract}
$\underline{\text { ABSTRACT }}$
The welfare aspects of dual exchange rate systems are analyzed in this paper. The requirement that domestic financial transactions with the rest of the world be undertaken at a special foreign exchange rate is found to be equivalent to levying a tariff on this class of international transactions. Hence, a dual exchange rate system and capital controls are shown to be essentially identical. In light of the above statements, the dual exchange rate system should be regarded as a form of commercial policy and be evaluated in this context by applying the applicable standard real trade theorems.
\end{abstract}

Please address all correspondence to:

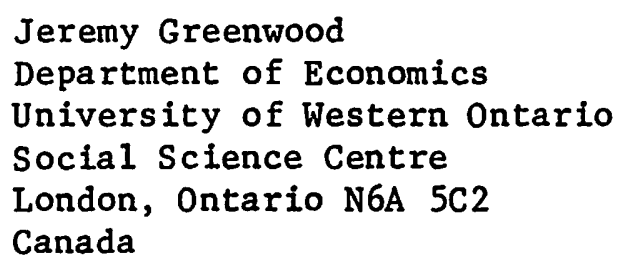




\section{Introduction}

The theoretical underpinnings and welfare properties of dual exchange rate systems are investigated in this paper using a simple choice-theoretic intertemporal general equilibrium model. Under a dual exchange rate system, transactions on the current and capital accounts must be effected using separate foreign exchange rates. While the exact form of this exchange rate system may vary according to different policy objectives that governments may have in mind, the essential idea is that these separate exchange rates can be regulated so as to achieve certain policy goals. The version of this exchange rate system to be analyzed here is one where the exchange rate for current account transactions (called the commercial exchange rate) is pegged across time while the exchange rate for capital account transactions (the financial exchange rate) is managed so as to attain a target level for the capital account. While not all dual exchange rate systems are operated in this fashion, an investigation of this principal case serves to highlight the salient characteristics of dual exchange rate regimes.

Most of the previous work on dual exchange rate regimes has been cast in terms of reduced-form macroeconomics. Some better-known examples of this work are Argy and Porter (1972), Dornbusch (1976), Flood (1978), Marion (1980), and Flood and Marion (1982). When focusing on the welfare aspects of any exchange rate regime, however, it may be more appropriate to conduct the discussion within a choice-theoretic setting, such as that outlined by Helpman (1981). This approach, which is taken here, may be preferable for a number of reasons. First, recent work in this vein has viewed movements in the current and capital accounts as reflections of optimizing agents' consumption-savings and investment decisions. For instance, see Obstfeld (1981), Sachs (1983), Svensson and Razin (1983), and Greenwood (1983). The intertemporal link between developments in today's capital account and future current accounts is clearly 
established in this line of theorizing. Thus, the intertemporal consequences of adopting a dual exchange rate system can be more clearly drawn. Second, this mode of analysis allows one to see explicitly how a dual exchange rate system impinges on the trading opportunities available to individuals and how it affects the incentive structure facing them. The consequences for economic efficiency can then be easily inferred. Last, often dual exchange rate systems have been evaluated on arbitrary criteria such as their ability to insulate an economy from various economic disturbances, say a change in world interest rates. It isn't always clear, however, why insulating an economy is a laudable goal and how it corresponds to maximizing an economy's welfare. By casting the current analysis in a choice-theoretic approach it is hoped that clear links between the adoption of a dual exchange rate system and economic welfare can be drawn. This should allow for the types of considerations to be employed in evaluating a dual exchange rate system to be precisely delineated.

It is shown in this paper that the dual exchange rate system affects both agents' consumption-savings and money-balance decision-making. The adoption of a dual exchange rate system turns out to be equivalent to levying a tariff on financial transactions with the rest of the world. Furthermore, dual exchange rate systems and systems of capital controls are isomorphic to one another in the same sense that tariffs and quotas are identical in the standard trade literature. Consequently, the same arguments that have been used traditionally to weigh the benefits of free trade versus restricted trade apply directly to assessing the desirability of the dual exchange rate system. As compared to a flexible exchange rate system, where the optimum quantity of money rule is being followed, the adoption of a dual exchange rate system can only reduce the welfare of a distortion-free small open economy. Finally, some insight into the operation of a dual exchange rate system is provided 
by an examination of its responsiveness to various exogenous disturbances, such as shocks to the terms of trade or world interest rates.

\section{The Individual's Optimization Problem}

Consider the case of the following "small" open economy that has adopted a dual exchange rate system. For simplicity, it will be assumed that this economy has a life span of two periods. It is inhabited by a representative agent whose goal is to maximize his lifetime utility, $\underline{U}(\cdot)$, as given by:

$$
\underline{U}(\cdot)=\sum_{t=1}^{2} \beta^{t-1} U\left(c_{t}\right)
$$

where $\beta$ is this individual's subjective discount factor and $c_{t}$ is period $t$ consumption of an imported good.

In each period $t$ the agent is endowed with a certain quantity of an export good denoted by $\bar{x}_{t}$. This export good can be exchanged for the imported good on world commodity markets. Under a dual exchange rate system, all transactions with foreigners involving the purchase or sale of goods are done at the commercial exchange rate. Let $e_{t}$ be the commercial exchange rate in period $t$, or the worth of a unit of foreign currency in terms of domestic currency when it is being used to facilitate the transactions of goods with the rest of the world. Arbitrage in world commodity markets would ensure that the law of one price (2.1) holds in each period.

$$
\begin{aligned}
& P_{t}=e_{t} P_{t}^{*} \\
& P_{x t}=e_{t} P_{x t}^{*}
\end{aligned}
$$

where $P_{t}$ and $P_{x t}$ are the domestic period $t$ nominal prices of the imported and exported goods, respectively, and $\mathrm{P}_{t}^{*}$ and $\mathrm{P}_{\mathrm{xt}}^{*}$ are the foreign nominal prices of these goods in this 
period. As was mentioned, under a dual exchange rate system, the commercial exchange rate is often pegged or fixed at some level, $\bar{e}$, implying that $e_{t}=\bar{e}$ for all $t$. Defining $\rho_{t}$ to be the world terms of trade in period $t$ so that $\rho_{t} \equiv P_{x t}^{*} / P_{t}^{*}=P_{x t} / P_{t}-$ that is, $\rho$ is the relative price of exports in terms of imports--it can be seen that the individual's endowment of exports in this period is worth $y_{t}$ units of imports where $y_{t}=\rho_{t} \bar{x}_{t}$. Also, in period $t$ the representative agent receives a real transfer payment, $t_{t}$, from the government.

The individual can hold two assets in this economy: domestic money and foreign nominal bonds. The individual holds money in order to economize on the transactions costs of exchange. In particular, in each period a certain fraction $v$ of the agent's real income, $y$, is absorbed in transactions costs. It will be assumed that $\mathrm{v}$ is a convex function of the ratio of the individual's nominal money balances, $M$, to his nominal income, Py. In other words, there are diminishing returns to holding money. By increasing his holdings of money, the agent can economize on the proportion of his real income which is being absorbed in transactions costs. As the ratio of money, $M$, to nominal income, Py, rises, however, the reduction in $v$ brought about by holding an extra unit of money is reduced. Formally,

$$
\begin{array}{cc}
v_{t}=v\left(M_{t} / P_{t} y_{t}\right) \quad & V_{t=1,2} \\
& \text { with } v^{\prime} \leq 0, v^{\prime \prime}>0
\end{array}
$$

The representative agent, in the first period, can also buy (or sell) a foreign denominated nominal bond which earns (or pays) the foreign nominal interest rate $i^{*}$. For instance, if in period one the individual was to buy a bond then worth one unit 
of foreign currency, he would earn $\left(1+i^{*}\right)$ units of foreign currency in period two. Now, under a dual exchange rate system, all financial transactions with the rest of the world must be made at the financial exchange rate. Specifically, if $s_{t}$ is the financial exchange rate in period $t$, then a unit of foreign currency used for financial transactions would be worth $s_{t}$ units of domestic currency. Thus, if in period one the representative agent invested a unit of domestic currency in foreign bonds, he would receive $1 / s_{1}$ units of these bonds. In the second period, these bonds would pay off $\left(1+i^{*}\right) / s_{1}$ units of foreign currency which at that time would be worth $(1+i *) s_{2} / s_{1}$ units of domestic currency. Under a dual exchange rate system, the government manages the financial exchange rate in such a manner so as to reduce capital account transactions to some target level.

The representative agent in this dual exchange rate economy would face the following constrained maximization problem with his choice variables being

$$
\begin{aligned}
& c_{1}, m_{1} \equiv M_{1} / P_{1}, \text { and } m_{2} \equiv M_{2} / P_{2}:^{3} \\
& \operatorname{Max} U\left(c_{1}\right)+\beta U\left(c_{2}\right) \\
& \text { s.t. } \\
& c_{2}=\left(1-v\left(\frac{m_{2}}{y_{2}}\right)\right) y_{2}+t_{2}+\left(1+i^{*}\right)\left(\frac{s_{2}}{s_{1}}\right)\left(\frac{P_{1}}{P_{2}}\right)\left[\left(1-v\left(\frac{m_{1}}{y_{1}}\right)\right) y_{1}+t_{1}\right. \\
& \left.\quad-c_{1}-m_{1}\right]-m_{2}+\left(P_{1} / P_{2}\right) m_{1}
\end{aligned}
$$

The first-order conditions associated with this maximization problem--in addition to $(2.2)--a r e:$

$$
\begin{aligned}
U^{\prime}\left(c_{1}\right) & =\beta\left[\frac{\left(1+i^{*}\right)}{(1+\pi)(1+f)}\right] U^{\prime}\left(c_{2}\right) \\
& =\beta(1+r) U^{\prime}\left(c_{2}\right) \quad \text { with } 1+r \equiv\left[\frac{\left(1+i^{*}\right)}{(1+\pi)(1+f)}\right]
\end{aligned}
$$




$$
\begin{aligned}
-v^{\prime}\left(\frac{m_{1}}{y_{1}}\right) & =\frac{i^{*}-f}{\left(1+i^{*}\right)} \\
& =\frac{i}{(1+i)} \quad \text { with } 1+i \equiv(1+\pi)(1+r)
\end{aligned}
$$

and

$$
\left.-v^{\prime}\left(\frac{m_{2}}{y_{2}}\right)=1 \quad \text { (Note that this implies } m_{2} / y_{2}=k \equiv v^{\prime-1}(-1) .\right) \quad(2.4 b)
$$

whree $\pi$ is the domestic inflation rate, or $\pi \equiv\left(P_{2}-P_{1}\right) / P_{1}$, and $f$ is the rate of appreciation in the financial exchange rate here defined as $f=-\left(s_{2}-s_{1}\right) / s_{2}$. Only the first two first-order conditions will be focussed on now. Equation (2.3) states that the individual should save until the loss in'first-period utility resulting from the drop in consumption due to shifting a small amount of resources into bonds exactly offsets the discounted gain in second-period utility following from increased future consumption, Note that by reducing current consumption by a real unit the individual could purchase $P_{1} / s_{1}$ units of foreign bonds that would pay off the equivalent of $(1+i *)\left(P_{1} / P_{2}\right)\left(s_{2} / s_{1}\right)=(1+i *) /[(1+\pi)(1+f)]$ consumption units next period. Thus, if $r$ is denoted as the real interest rate facing domestic residents, then $1+r=$ $\left(1+i^{*}\right) /[(1+\pi)(1+f)]$.

Equation (2.4a) sets the marginal product of money in period one, or $-v^{\prime}\left(m_{1} / y_{1}\right)$, equal to the opportunity cost of holding money in this period, or $(i *-f) /\left(1+i^{*}\right)$. It is easy to see that $\left(i^{*}-f\right) /\left(1+i^{*}\right)$ is the opportunity cost of holding a unit of real balances in period one. To finance the holding of an additional unit of real balances in period one, the individual could issue a foreign nominal bond in the amount $\mathrm{P}_{1} / \mathrm{s}_{1}$. The individual would then have to pay the purchaser of this bond $\left(1+i^{*}\right) \mathrm{P}_{1} / \mathrm{s}_{1}$ units of foreign currency next period. This would be worth $\left(1+1^{*}\right)\left(P_{1} / P_{2}\right)\left(s_{2} / s_{1}\right)$ $=(1+i *) /[(1+f)(1+\pi)]$ units of domestic consumption at that time. But this would not be the real cost that the individual would incur in the second period in order to 
increase his first period holdings of real balances by a unit. In the second period, the individual would still have $P_{1}$ units of nominal balances that he has carried over from the first period and that would now be worth $P_{1} / P_{2}=1 /(1+\pi)$ units of consumption goods. Thus, the second-period cost the agent would incur would be $\left(1+i^{*}\right) /[(1+f)(1+\pi)]$ $-T /(1+\pi)=\left(i^{*}-f\right) /[(1+f)(1+\pi)]$. To obtain the cost in terms of first-period consumption, one should discount the above term by one plus the real interest rate, or $(1+i *) /[(1+\pi)(1+f)]$. By doing this, it can be seen that the opportunity cost of holding money in our dual exchange rate environment is $(i *-f) /(1+i *)$.

Now, define $i$ as the domestic nominal interest rate so that $1+i=(1+\pi)(1+r)$. It is easy to see that the opportunity cost of holding money may be written as $i /(1+i)$. That $i s, i /(1+i)=(i *-f) /(1+i *)$. The rate of appreciation in the financial

exchange rate, or $f$, affects the opportunity cost of holding money because it influences the domestic nominal interest rate, $i$, via its impact on the domestic real interest rate, $r .4,5,6$

Note that since the commercial exchange rate is fixed under a dual exchange rate, the law of one price $(2.1)$ implies that domestic and foreign inflation rates must be the same. That is, $\pi=\pi^{*}$ where $\pi^{*}$ is defined as the foreign $r$ ate of inflation, so that $\pi^{*} \equiv\left(\mathrm{P}_{2}^{*}-\mathrm{P}_{1}^{*}\right) / \mathrm{P}_{1}^{*}$. Thus, one could replace $\pi$ by $\pi^{*}$ in equations $(2.3)$ and (2.4a) and elsewhere in the model. The world real interest rate, $r^{*}$, is given by the equation $1+r^{*}=\left(1+i^{*}\right) /\left(1+\pi^{*}\right)$. Consequently, domestic and foreign real interest rates, $r$ and $r^{*}$, have the following relationship with one another: 7

$$
\begin{aligned}
1+r & =\left(1+r^{*}\right) /(1+f) \\
& =\left(1+r^{*}\right)\left[1-\frac{f}{1+f}\right]
\end{aligned}
$$

As can be seen, a dual exchange rate system can be viewed as effectively imposing a tax--or tariff--on domestic financial transactions with the rest of the world. A 
tax at the rate $\frac{f}{1+f}$ is being levied on the principal and interest derived from the savings that the domestic economy does with the rest of the world.

Finally, the above optimization problem of the consumer suggests that the agent's compensated demand function for first-period consumption should take the following form:

$$
c_{1}=c(\underset{(t)}{f}, \underset{(t)}{\omega})
$$

where $\omega$ is an index of the individual's lifetime utility. It also suggests that his first-period demand for money function should appear as

$$
m_{1}=\underset{(f)}{m(f) y_{1}}
$$

The sign under an argument in one of the demand functions shows the sign implied by the consumer's problem of the partial derivative of that demand function with respect. to the argument in question.

\section{The Mode1's General Equilibrium}

Like any other actor in the economy, the government must satisfy a budget constraint. To facilitate the analysis it is helpful to artificially split up the government into two sectors: viz a central bank and an authority which manages the financial exchange rate. This dichotomization does not affect the model's generality. The central bank's purpose is to provide the economy's money stock and to maintain the commercial rate fixed at the level $\bar{e}$. The central bank's budget constraint for the first period is:

$$
\mathrm{b}+\mu_{1}=\mathrm{m}_{1}
$$

where $b$ is defined to be the real value--measured in terms of imports--of the central 
bank's acquisitions of foreign nominal bonds in the first period and $\mu_{1}$ is the value of transfer payments that it makes to domestic residents in this period. Changes in $b$ can be thought of as reflecting movements in the current balance of payments while fluctuations in $\mu_{1}$ can be regarded as shifts in domestic credit. The central bank's second-period budget constraint appears as

$$
\begin{aligned}
\mu_{2}=m_{2}- & \left(\frac{1}{1+\pi}\right) m_{1}+\left(1+r^{*}\right) b \\
& \left(\text { Recall that } 1+r^{*} \equiv\left(1+i^{*}\right) /\left(1+\pi^{*}\right) .\right)
\end{aligned}
$$

where $\mu_{2}$ is the real value of transfer payments made by the central bank in period two. As was just mentioned, it is convenient to split up the government into two agencies. The second agency is responsible for managing the financial exchange rate and will be dubbed the Financial Exchange Rate Authority (FERA). The FERA's firstperiod budget constraint is

$$
\begin{aligned}
& \tau_{1}=\left(1-\frac{\bar{e}}{s_{1}}\right) a \\
& \text { with } \left.a \equiv(1-v(1)) y_{1}+t_{1}-c_{1}-m_{1} \quad \text { [Note } v(1) \equiv v\left(\frac{m_{1}}{y_{1}}\right) .\right]
\end{aligned}
$$

where $\tau_{1}$ is real value of transfer payments that the FERA makes to domestic residents, and $a$ is the amount of private-sector real resources that domestic residents use to purchase foreign nominal bonds. (Note that consistency in the model requires that the aggregate value of first-period transfer payments made by the government is equal to the sum of transfer payments made by the central bank, $\mu_{1}$, and the FERA, $\tau_{1}$, i.e., $t_{1}=\mu_{1}+\tau_{1}$ ) The left-hand side of the above equation represents the FERA's firstperiod expenditure while the right-hand side shows its revenues in this period. To gain some insight into the nature of this revenue, note that domestic residents in 
order to purchase foreign bonds sell resources to the FERA worth a units of imports. In exchange for these resources, the FERA gives them $\left(\frac{P_{1}}{s_{1}}\right)$ a nominal units of foreign currency. At world prices this would be worth $\left(\frac{\mathrm{P}_{1}}{\mathrm{~s}_{1} \mathrm{P}_{1}^{*}}\right)$ a units of imports. Using the law of one price (2.1) it follows that the foreign exchange authority is giving the public foreign exchange worth $\left(\frac{\bar{e}}{s_{1}}\right)$ a units of imports in return for domestic resources worth a units. Thus the revenue earned by the FERA in the first period is the difference between these two sums or $\left(1-\frac{\bar{e}}{s_{1}}\right) a$. The FERA's second-period budget constaint is

$$
\tau_{2}=\left(\frac{\bar{e}-s_{2}}{s_{1}}\right)\left(1+r^{*}\right) a
$$

where $\tau_{2}$ is the real value of its second-period transfer payments. (Again, note that $t_{2}=\mu_{2}+\tau_{2}$ ) The term on the right-hand side of the above expression illustrates the earnings the FERA makes from its operations in the second period. This term is easy to explain. In the second period domestic residents will have foreign currency worth $\left(\frac{\bar{e}}{s_{1}}\right)\left(1+r^{*}\right)$ a units of imports--again the foreign exchange is being evaluated at international prices. The foreign exchange authority, however, gives them domestic currency worth only $\left(\frac{s_{2}}{s_{1}}\right)\left(1+r^{*}\right)$ a units of imports. The FERA's earnings in the second period are given by the difference between these two sums.

As has been mentioned, the objective of a dual exchange rate system is to reduce capital account transactions to some target level. The FERA sets the rate of appreciation in the financial exchange rate, $f$, so as to achieve this target. In other words, as can be seen from $(2.5)$, the FERA taxes--or subsidizes when $f$ is negative--the proceeds from domestic saving so as to manipulate (one plus) the domestic real interest rate in order to bring domestic financial transactions with the rest of the world into line with this target. "Assume that the government wants 
the magnitude of the capital account in the first period to be $\overline{c a}$. This implies that it must set net external savings by domestic residents equal to -ca. Now recall that while the private sector is giving the FERA domestic resources worth a units of imports, they are receiving in return foreign bonds worth only $\left(\frac{\bar{e}}{s_{1}}\right)$ a units of imports--again, the difference between these two sums represents the FERA's firstperiod profits. In other words, net external savings by domestic residents is really $\left(\frac{\bar{e}}{s_{1}}\right) a$. Consequently, it follows that

$$
-\left(\frac{\bar{e}}{s_{1}}\right) a=\overline{c a}
$$

By using the above condition (3.5) in conjunction with the representative agent's budget constraint (2.2), the government's budget constraints (3.1), (3.2), (3.3) and (3.4), it is apparent that an implication of a dual exchange rate system is that

$$
\begin{aligned}
& c_{1}=(1-v(1)) y_{1}-b+\overline{c a} \\
& c_{2}=(1-v(k)) y_{2}+\frac{\left(1+i^{*}\right)}{\left(1+\pi^{*}\right)} b-\frac{\left(1+i^{*}\right)}{\left(1+\pi^{*}\right)} \overline{c a} \\
& \quad\left[\text { Recal1 from }(2.4 b) \text { that } k \equiv v^{\prime-1}(-1) .\right] \\
& m_{1}=\mu_{1}+b \\
& m_{2}=\mu_{2}+\left(\frac{1}{1+\pi^{*}}\right) m_{1}-\frac{\left(1+i^{*}\right)}{\left(1+\pi^{*}\right)} b
\end{aligned}
$$

The interpretation of the above equations is obvious. For instance (3.6) shows that a familiar identify holds for the first period: the sum of the current account, $(1-v(1)) y_{1}-c_{1}$, plus the capital account, $\overline{c a}$, must equal the balance of payments, $b$. 
IV. Three Comparative Statics Exercises

In order to gain some further insight into the nature of tual exchange rate systems, three comparative statics exercises will be undertaken. First, suppose that an anticipated improvement in the future terms of trade, $\rho_{2}$, occurs. (In other words, let $\rho_{2}$ increase while holding $\rho_{1}$ fixed.) How will this affect the rate of appreciation in the financial exchange rate, $f$, and the balance of payments, $b$ ? To answer this question one should focus on equations $(2.6),(2.7),(3.6)$ and $(3.8)$ which imply in equilibrium that the following holds:

$$
\begin{aligned}
& c(f, w)=\left(1-v\left(\frac{m_{1}}{y_{1}}\right)\right) y_{1}-b+\overline{c a} \\
& m(f) y_{1}=\mu_{1}+b
\end{aligned}
$$

Now, an increase in the future terms of trade, $\rho_{2}$, leads to a change in the agent's real welfare--see Appendix for further details--of the amount

$$
\begin{aligned}
\mathrm{d} w & =\frac{(1-v(k)) \overline{\mathrm{X}}_{2}}{(1+r)} \mathrm{d} \rho_{2}+\frac{r^{*}-r}{(1+r)} \mathrm{db}-\mathrm{v}^{\prime}(1) \mathrm{db} \\
& =\frac{(1-v(k)) \overline{\mathrm{X}}_{2}}{(1+r)} \mathrm{d} \rho_{2}+\frac{i *(1+f)}{\left(1+i^{*}\right)} \mathrm{db} \quad \text { (using (2.4a) and (2.5)) }
\end{aligned}
$$

where $d \omega$ is the individual's welfare gain when measured in terms of current consumption. As can be seen from (4.3), this change in the agent's real welfare can be broken down into three components. The first component represents the present discounted value of the change in agent's future real income net of transactions costs. Note that the agent uses the domestic real interest rate, $r$, to discount his future income. (Recall that $\left.1+r=\left(1+r^{*}\right) /(1+f).\right)$

The second component represents the welfare gain realized by the individual when the government increases its holdings of foreign reserves in the first period by $\mathrm{db}$. Note that when the government increases its foreign reserves in the first period by a unit, equation (3.6) implies that private coisumption falls in this period by a unit. Now, as can be seen from (3.7), the agent's future consumption will increase 
by $\left(1+r^{*}\right)$ units when the government's current reserves increase by a unit. But the agent would require only $1+r$ units of future consumption to compensate him for a unit loss in current consumption, a fact (2.3) illustrates. Thus, the agent is gaining an additional $r^{*}-r$ units of second-period consumption over and above the amount he would be willing to accept to cut back his first-period consumption by a unit. This net gain in future consumption goods, $r *-r$, is of course worth $(r *-r) /(1+r)$ units of current consumption. Consequently, on net, the representative agent incurs a welfare gain in the amount of $\left(r^{*}-r\right) /(1+r)$ units of present consumption when the government increases its current reserves by a unit. In a distortion-free competitive equilibrium, changes in the central bank's holding of interest-bearing reserves should not affect agents' welfare levels, a fact Obstfeld (1982), Stockman (1983) and Persson (1984) discuss. Ricardian equivalence fails to hold in the current model because the real interest rate at which the government borrows and lends, $\mathrm{r}^{*}$, is not the same as that used by private agents in their consumption-savings decision, $r$. (See $(2.5)$ where $r=r *-[f /(1+f)](1+r *)$. As discussed, the term $[f(1+f)]$ represents the tariff wedge introduced by dual exchange rate system.)

The third component illustrates the welfare gain the individual enjoys due to the fact that current transactions costs fall when today's real supply of money, $m_{1}$, rises because the government's holdings of foreign reserves increases by the amount $\mathrm{db}$. When real balances increase by a unit, transactions costs decrease by the amount $\left(i^{*}-f\right) /\left(1+i^{*}\right)$-note that $-v^{\prime}(1)=\left(i^{*}-f\right) /\left(1+i^{*}\right)$ from $(2.4 a)$. (The fact that $v^{\prime}(1) \neq 0$ also results from a distortion present in the economy. This is discussed later on.) The net effect of the second and third terms on the agent's real welfare is positive, as is shown by (4.3a).

The impact of an increase in $\rho_{2}$ on $f$ and $b$ can be uncovered by subjecting equations $(4.1)$ and $(4.2)$ to the usual sort of comparative statics exercise while making use of (4.3). The results of this exercise are ${ }^{9}$ 


$$
\frac{\mathrm{df}}{\mathrm{d} \rho_{2}}=-\frac{\left[(1 /(1+r))(1-v(k)) \bar{x}_{2}\right] \frac{\partial c}{\partial \omega}}{\Omega}<0
$$

where $\quad \Omega \equiv\left\{\left.\frac{\partial c}{\partial f}\right|_{\omega=\bar{\omega}}+\left[(1+f)\left(1+i^{*} \frac{\partial c}{\partial \omega}\right) /(1+i *)\right]\left(\frac{\partial m}{\partial f}\right) y_{1}\right\}>0$, and

$$
\left.\frac{d b}{d \rho_{2}}=\left(\frac{\partial m}{\partial f}\right) y_{1}\left(\frac{d f}{d \rho_{2}}\right)<0 \quad \text { (since } \frac{d f}{d \rho_{2}}<0\right)
$$

An increase in the future terms of trade, $\rho_{2}$, causes the current financial exchange rate to appreciate relative to its future value, i.e., $f$ falls. This is what (4.4) shows. This expression can be explained intuitively as follows. When the agent's future real income, $y_{2}=\rho_{2} \bar{x}_{2}$, rises he feels wealthier today. At the initial value of $f$, rather than consume this increase in wealth solely in the second period, the agent instead wants to smooth out this gain in his wealth over both periods, and hence desires to increase his current consumption. When $f$ remains fixed, the agent's current disposable income remains unaltered so that the only way the individual would increase his current consumption would be by borrowing on the international bond market. This attempt to borrow causes $f$ to fall, so that one plus the domestic real interest rate on loans, $1+r=(1+i *) /\left(1+\pi^{*}\right)(1+f)$, increases and the capital account, $\overline{c a}$, remains fixed.

This decrease in $f$ is positively associated with $\partial c / \partial w$ which shows how an increase in wealth--at a constant value of f--affects current consumption, $c_{1}$. Also, note that this movement in $f$ is inversely related to the size of $\partial_{c} /\left.\partial_{f}\right|_{\omega=\bar{\omega}}$ which represents the substitution effect of a change in $f$ on current consumption. The bigger this substitution effect is, or the more willing the agent is to substitute away from current consumption toward future consumption as $f$ falls, the smaller will be the decline in $f$.

The magnitude of this downward movement in $f$ is negatively related to the size of $\left(\partial_{m} / \partial_{f}\right) y_{1}$ which shows the impact of a change in $f$ on the current demand for real balances. As $f$ falls, the opportunity cost, $i /(1+i)=(i *-f) /(1+i *)$, of holding 
real balances increases since the domestic nominal interest rate has risen and this results in people holding less real balances. An outflow of foreign reserves will then occur. Now recall that a unit loss in the government's foreign reserves will lead to a reduction in individuals' welfare by the amount $(1+f) i * /(1+i *)--$ c.f. (4.3a). On this account, agents will desire to reduce their current consumption by $[(1+f) i * /(1+i *)] \partial c / \partial \omega$. Also, a unit reduction in the government's foreign reserves will lead to an increase in the supply of current consumption goods available to private citizens by the amount $1+v^{\prime}(1)=(1+f) /\left(1+i^{*}\right)$, a fact which is readily apparent from the right-hand side of (4.1). Thus, the net effect of a unit reduction in the government's foreign reserves, brought about by a unit reduction in the demand for money, would be to create an excess supply of current consumption goods of $(1+f)\left[1+i^{*}(\partial c / \partial \omega)\right] /\left(1+i^{*}\right)$ units. Therefore, there would be less need for current borrowing and this would have a dampening effect on the fall in $\mathrm{f}$.

Finally, as was just mentioned, when $f$ falls this causes the demand for real balances to drop, and hence the government's holdings of foreign reserves to fall as (4.5) portrays. First, this drop in the government's foreign reserves will be related to the sensitivity of the demand for real balances with respect to changes in $f$ which is governed by the size of $(\partial \mathrm{m} / \partial f) y_{1}$. Second, it will be proportional to the magnitude of the change in $f$ itself as given by $\mathrm{df} / \mathrm{d} \rho_{2}$.

Note from (3.6) that as a consequence of the improvement in the future terms of trade, $\rho_{2}$, the trade balance will tend to swing into deficit. That is, $(1-v(1)) y_{1}-c_{1}$ will tend to fall since b drops while $\overline{c a}$ remains fixed. In a distortion-free competitive equilibrium one would expect a trade balance deficit to occur in response to an increase in future income as domestic residents dipped into their savings or borrowed in order to finance greater current consumption. This 
result is discussed by Sachs (1983), Svensson and Razin (1983), and Greenwood (1983). In the present setting the increase in private consumption, $c_{1}$, is being financed by the central bank running down its reserves, b. The central bank is effectively acting as a financial intermediary here.

For the second comparative statics exercise, suppose that the government decides to increase its target level for the capital amount, $\overline{c a}$. What would the impact of this decision be on the rate of appreciation in the financial exchange rate, $f$, and the balance of payments, $b$ ? Following the procedure outlined in the discussion of the previous comparative statics exercise the change in the agent's real welfare as a consequence of this policy would be

$$
d \omega=\frac{i^{*}(1+f)}{\left(1+i^{*}\right)} d b-f \overline{d c a}
$$

The change in the agent's real welfare is made up of two components, as the right-hand side of (4.6) illustrates. These two components were explained in the previous comparative statics exercise and hence will not be discussed again here.

By undertaking the desired comparative statics exercise on equations (4.1) and (4.2), while utilizing (4.6), one obtains the following results ${ }^{10}$

$$
\begin{aligned}
\frac{\mathrm{df}}{\overline{d c a}}=\frac{\left[1+f \frac{\partial c}{\partial w}\right]}{\Omega} & >0 \\
& \left(\text { since } 1+\mathrm{f} \frac{\partial c}{\partial w}>0 \text { as } \frac{\partial c}{\partial w}<1 \text { and } \mathrm{f}>-1\right)
\end{aligned}
$$

and

$$
\frac{d b}{d c a}=\left(\frac{\partial m}{\partial f}\right) y_{1} \frac{d f}{d c a}>0
$$

Equation (4.7) illustrates that an increase in the government's target level for the capital account, $\overline{c a}$, will lead to a rise in the rate of appreciation in the financial exchange rate, $f$, or equivalently will cause a downward movement in the 
domestic real interest rate, $r$. This is intuitively obvious: a lower equilibrium domestic real interest rate is required in order to entice domestic residents to save the reduced requisite amount--recall that $\overline{c a}=-a /(1+f)$.

The analogy between dual exchange rate systems and capital controls is readily apparent. Under a dual exchange rate system the government picks a target for the capital account, $\overline{c a}$, and sets the rate of appreciation in the financial exchange rate, $f$, so as to force domestic savings into line with this target. As (2.5) illustrates, effectively the government is levying a tax on private financial transactions undertaken with the rest of the world. This is parallel to a govenment levying a tariff on imports so as to achieve some import goal. Now, capital controls are analogous to quotas on imports. It is well-known in the international trade literature that tariffs and quotas are identical under certain conditions, as is discussed by Bhagwati (1965). In the current situation one could imagine the government setting quotas on private financial transactions with the rest of the world in the amount ca. If the government allocated the rights to these quotas so as to maintain perfect competition among quota holders then the domestic real interest would be identical under either a system of dual exchange rates or capital controls. 11 That is, in this situation, the two systems are isomorphic to each other $0^{12,13,14}$

Finally, also note from $(4.8)$ that when the government increases its target level for the capital account a balance of payments surplus is likely to occur. This is because as the domestic real interest, $r$, falls so does the opportunity cost of holding money, $i /(1+i)$. The resulting rise in the demand for money will create a propensity toward a balance of payments surplus.

For the last comparative statics exercise, consider how an increase in the world nominal interest rate, $i *$, affects the rate of appreciation in the financial exchange rate, $f$, and the balance of payments, $b$. (Since the world inflation rate, $\pi^{*}$, is being held fixed here, effectively an upward shift in the world interest rate, $r^{*}$, is 
is being discussed.) Just the results of this will be formally shown since the essential analytical steps needed to derive them mimic those employed in the previous two exercises. The effects on the economy in the current case are:

$$
\begin{aligned}
& \frac{d f}{d i^{*}}=\left[(1+f) /\left(1+i^{*}\right)\right]\left\{1-[(b-\overline{c a}) / \Omega] \frac{\partial c}{\partial \omega}\right\} \stackrel{?}{\gtrless} 0 \\
& \frac{d b}{d i^{*}}=-\left\{\left[(1+f) /\left(1+i^{*}\right)\right][(b-\overline{c a}) / \Omega] \frac{\partial c}{\partial w}\right\} \frac{\partial m}{\partial f} y_{1} \stackrel{?}{\gtrless} 0
\end{aligned}
$$

To begin with, the consequence of a world nominal interest change on the financial exchange rate's rate of appreciation, or (4.9), will be discussed. It can be seen, strictly speaking, that the sign of this expression is ambiguous. In general, any change in a world price will have both income and substitution effects on a small economy's equilibrium. The sign and magnitude of any price change's impact depends upon how these two effects weigh in. This is also true in the current situation, where here the sign of the income effect depends on whether the domestic country is a net international creditor or debtor, $i . e .$, on whether $b-\overline{c a}$ is positive or negative.

To illustrate further how the above general considerations enter into (4.9) specifically, suppose that the domestic country is neither a net international creditor or debtor. In this case $b-\overline{c a}$ is zero and the income effect from a world interest rate change vanishes. The substitution effect from a rise in the world interest rate would then dictate that the rate of appreciation in the financial exchange rate increase. In other words, here $(4.9)$ would be positive. The intuitive rationale for this result is perhaps obvious. To see this, note that if the government still wants to maintain its target level for the capital account, $\overline{c a}$, it must ensure that the domestic real interest rate, $r$, remains constant. $\left\{\right.$ Recall that $1+r=\left(1+i^{*}\right) /$ $\left.\left[\left(1+\pi^{*}\right)(1+f)\right].\right\}$ To do this, the government must let the rate of appreciation of the financial exchange rate rise so as to offset the increase in the foreign nominal 
interest rate, $i^{*}$. Specifically, as can be deduced from (4.9), this requires that $\mathrm{df} / \mathrm{d} \mathrm{i}^{*}=(1+f) /\left(1+i^{*}\right)$. Next, note that in this case the balance of payments is unaffected by a change in the foreign nominal interest rate--cf. (4.10). This occurs because the domestic opportunity cost of holding money, $i /(1+i)=\left(i^{*}-f\right) /\left(1+i^{*}\right)$, also remains constant here.

Finally, suppose that the domestic country was a net creditor internationally so that $b-\overline{c a}$ was positive. Now a change in the foreign nominal interest rate would have a positive income effect on the economy. As a consequence of this, the individual would like to consume more and save less in the current period. In order to maintain the capital account at its target level, the domestic real interest rate must be increased. This is accomplished by letting the rate of appreciation in the financial exchange rate increase to a lesser extent than it did in the previous case--in which a constant domestic real interest rate was maintained. This is shown by (4.9). A1so, it can now be seen that the domestic opportunity cost of holding also rises now which causes a balance of payments deficit as (4.10) illustrates. 15

\section{The Optimum Choice of Exchange Rate Regime}

How should an economy choose its exchange rate regime? This question has been examined by Helpman (1981), and subsequently by Aschauer and Greenwood (1983), and Greenwood (1983). To address this question in the current context, imagine that this economy is controlled by a central planner whose aim is to maximize individuals' lifetime utility. The optimization problem the central planner should solve is shown below where $c_{1}$ and $m_{1}$ are his choice variables.

$$
\begin{aligned}
& \operatorname{Max} U\left(c_{1}\right)+\beta U\left(c_{2}\right) \\
& \text { s.t. } c_{2}=(1-v(k)) y_{2}+\frac{\left(1+i^{*}\right)}{\left(1+\pi^{*}\right)}\left[(1-v(1)) y_{1}-c_{1}\right]
\end{aligned}
$$

The first-order conditions arising from this maximization problem--in addition to the 
general equilibrium budget constraint (5.1)--are

$$
\begin{aligned}
& U^{\prime}\left(c_{1}\right)=\beta \frac{\left(1+i^{*}\right)}{\left(1+\pi^{*}\right)} U^{\prime}\left(c_{2}\right) \\
& -v^{\prime}\left(\frac{m_{1}}{y_{1}}\right)=0
\end{aligned}
$$

To help understand the inefficiencies that a dual exchange rate system introduces into an economy, it is useful to contrast the above two first-order conditions with those that arise in the dual exchange rate economy.

A comparison of (5.2) with its analogue $(2.3)$ is the dual exchange rate economy illustrates how agents' consumption-saving decisions are distorted in a dual exchange rate environment. It can easily be seen from (5.2) that economic efficiency requires that the marginal rate of substitution between future and current consumption $\mathrm{U}^{\prime}\left(c_{1}\right) / \beta \mathrm{U}^{\prime}\left(c_{2}\right)$, be equated to one plus the world real interest rate, $\left(1+i^{*}\right) /\left(1+\pi^{*}\right)$. In the dual exchange rate economy, a wedge of the amount $\left(1+\pi^{*}\right) /[(1+\pi)(1+f)]$ is driven between those two quantities. Now, let $\delta$ represent the rate of appreciation in the commercial exchange rate where $\delta$ is formally defined as $\delta=-\left(e_{2}-e_{1}\right) / e_{2}$. The law of one price $(2.1)$ implies in general that $(1+\delta)=\left(1+\pi^{*}\right) /(1+\pi)$. Consequent ly, the wedge in question could be rewritten as $(1+\delta) /(1+f)=[1+(\delta-f) /(1+f)]$. Thus, it follows that the distortion in the agent's consumption-saving decisions induced by the dual exchange rate system could be removed by letting the commercial and financial exchange rates appreciate at the same rate. In other words, economic efficiency dictates that $f=\delta$. This, of course, implies that the dual exchange rate system should be abandoned.

By comparing equation (5.3) with its dual exchange rate system analogue, (2.4a), it can be seen how agents' money demand decisions are distorted in a dual exchange rate system environment. Equation (5.3) states that economic efficiency necessitates that money's marginal product be set equal to its marginal (social) cost which is zero 
when money is costless to produce. Individuals under a dual exchange rate system, however, perceive the opportunity cost of holding money to be $\left(i^{*}-f\right) /\left(1+i^{*}\right)$ which is not equal to the social opportunity cost--zero--of holding money. This results in money being underutilized, and the real transaction costs of exchange being too high, in the dual exchange rate economy. The private opportunity cost of holding money can be reduced to the social opportunity cost of holding money by letting the financial exchange rate appreciate at the rate $f=i^{*}$. That is, the financial exchange rate should appreciate at the foreign nominal interest rate.

To conclude this section, economic efficiency requires that $\delta=f=i *$. In other words, a "small" open economy should adopt a flexible exchange rate system and follow the optimum quantity of money rule in order to maximize its welfare. This is easy to see since the law of one price (2.1) implies that when $\delta=i *$, the domestic economy is deflating according to the optimum quantity of money rule. That is,

$$
\pi=-r^{*} /\left(1+r^{*}\right) \quad \text { where again }\left(1+r^{*}\right) \equiv\left(1+i^{*}\right) /\left(1+\pi^{*}\right)
$$

where $\mathrm{r}^{*}$ is the world real interest rate. This result is also shown in Aschauer and Greenwood (1983) and Greenwood (1983). The fact that a "small" open economy should abandon a dual exchange rate system should be appealing to the international economist. 16 Free trade in goods for a "small" open economy is taken for granted as being desirable for such an economy, and it consequently seems a small step to argue that free trade in financial assets is also inherently desirable.

\section{Conclusions}

To summarize, dual exchange rate systems can be characterized as a form of protectionism. Under this exchange rate system, a separate exchange rate is required for international financial transactions. The government can manipulate this exchange rate so as to achieve various policy objectives, such as a target level for the 
capital account. ${ }^{17}$ This exchange rate system was shown to be equivalent to levying a tariff on international financial transactions. Also, it was noted that dual exchange rate systems and capital controls can be thought of as being equivalent in the same sense that the standard trade literature views tariffs and quotas to be. In a distortion-free competitive equilibrium, dual exchange rate systems would clearly be undesirable for a small open economy. This conclusion is a straightforward application of the standard trade result that free trade is better than restricted trade in such circumstances. In a distortion-ridden small open economy dual exchange rate systems could improve welfare because restricted trade may be better than free trade in such environments. The task for proponents of dual exchange rate systems should be to identify the domestic distortions which these exchange rate systems aim to ameliorate, and to explain why such exchange rate policies are likely to dominate alternative commercial policies。 ${ }^{18}$ Most work in international finance analyzing dual exchange rate systems has not been oriented along these lines. 


\section{APPENDIX}

In this appendix a demonstration of the welfare gain the agent realizes today when the future terms of trade, $\rho_{2}$, are anticipated to improve will be undertaken. Recall that the individual's lifetime utility is

$$
\underline{U}=U\left(c_{1}\right)+B U\left(c_{2}\right)
$$

so that

$$
\mathrm{dU}=\mathrm{U}^{\prime}\left(c_{1}\right) \mathrm{dc} c_{1}+\beta \mathrm{U}^{\prime}\left(c_{2}\right) \mathrm{dc} c_{2}
$$

Now, divide both sides of the above equation by $U^{\prime}\left(c_{1}\right)$ and define $\mathrm{d} \omega \equiv \mathrm{dU} / \mathrm{U}^{\prime}\left(c_{1}\right)$ as the change in the agent's real welfare evaluated in terms of current imports.

$$
d \omega=d c_{1}+\beta \frac{U^{\prime}\left(c_{2}\right)}{U^{\prime}\left(c_{1}\right)} d c_{2}
$$

From the agent's first-order condition $(2.3)$, it can be seen that $\beta U^{\prime}\left(c_{2}\right) / U^{\prime}\left(c_{1}\right)$ $=(1+f)\left(1+\pi^{*}\right) /\left(1+i^{*}\right)$, implying that

$$
\mathrm{d} \omega=\mathrm{dc} 1+\frac{(1+f)\left(1+\pi^{*}\right)}{\left(1+i^{*}\right)} \mathrm{dc} c_{2}
$$

But from equations (3.6) and (3.7), as well as from equations (3.8) and (2.4b), it is known that in the dual exchange rate economy's general equilibrium the following must be true:

$$
\begin{aligned}
& d c_{1}=-d b-v^{\prime}(1) d b \\
& d c_{2}=(1-v(k)) \bar{x}_{2} d \rho_{2}+\frac{\left(1+i^{*}\right)}{\left(1+\pi^{*}\right)} d b \quad\left[\text { Recall that } y_{2}=\rho_{2} \bar{x}_{2} \cdot\right]
\end{aligned}
$$

Thus,

$$
\begin{aligned}
d \omega & =\frac{(1+f)\left(1+\pi^{*}\right)}{\left(1+i^{*}\right)}(1-v(k)) \bar{x}_{2} d \rho_{2}+f d b-v^{\prime}(1) d b \\
& =\frac{(1-v(k)) \bar{X}_{2}}{(1+r)} d \rho_{2}+f d b-v^{\prime}(1) d b .
\end{aligned}
$$


Finally, through the use of (2.5) it can be seen that

$$
d w=\frac{(1-v(k)) \bar{x}_{2}}{(1+r)} d \rho_{2}+\frac{r^{*}-r}{(1+r)} d b-v^{\prime}(1) d b
$$

which is equation (4.3) in the text. 
Footnotes

We would like to thank Peter Garber, Kent Kimbrough, Torsten Persson and two anonymous referees for helpful comments. Any remaining errors are ours.

${ }^{1}$ An exception is Obstfeld (1984) who analyzes the determination of the dual (financial) exchange rate within a choice-theoretic framework.

${ }^{2}$ Similar two-period setups have been used by Persson (1983), Sachs (1983), Stockman (1983), Svensson and Razin (1983), and Greenwood $(1983,1984)$ to address various problems in international finance.

3 Note that no assets--neither money nor bonds--are being carried over into the first period. That is, in effect, the world is being "started up" in the first period.

4 Note that it is the rate of appreciation in, and not the level of, the financial exchange rate that is relevant for the representative agent's decision-making. This is because the domestic real interest rate, which is central to both the individual's consumption-saving and money balance decisions, is determined by the rate of appreciation in the financial exchange rate. See also Dornbusch (1976).

${ }^{5}$ An alternative form of the dual exchange rate system is one which lets domestic residents repatriate interest income at the commercial exchange rate--see Flood and Marion (1982). The reader can check for himself that in the current model this would imply that the domestic real interest rate, $r$, is now given by the expression $1+r=\left[1+\left(\bar{e} / s_{2}\right) i *\right] /[(1+\pi)(1+f)]$. Also, the opportunity cost of holding money, $i /(1+i)$, would now be described by the formula $i /(1+i)=\left[\left(\bar{e} / s_{2}\right) i *-f\right] /\left[1+\left(\bar{e} / s_{2}\right) i *\right]$. The setting adopted in the text was chosen because it was algebraically the most tractable, yet still captured the essential features of a dual exchange rate system. There are practical reasons for implementing one form of a dual exchange rate system over another-such as the enforceability and viability of the various systems over the long run due to the different implications they may have for spread between the commercial and financial exchange rates-but these are of secondary importance for the analysis being undertaken here. 
${ }^{6}$ Note that at the end of the second period the real value of the agent's cash balances is completely written off. This explains the form of (2.4b) which sets money's marginal product equal to unity; the private opportunity cost of holding a unit of real balances in the second period is a forgone unit of consumption. In any finite horizon model, where money is circulating as a medium of exchange, this perhaps begs the question as to why anyone would want to be the last person to hold money as the end of the world approaches. Such questions are abstracted from here essentially by modelling money as an input into the production of output.

${ }^{7}$ Fleming (1974) and Lanyi (1975), in less formal discussions, have also observed this point.

8 Note that the government's revenues in each period depend upon the spread between the values of the financial and commercial exchange rates. (Specifically, in period one they depend upon $s_{1}-\bar{e}$ while in period two they depend on $\bar{e}-s_{2} \cdot$ ) If the tinancial and commercial exchange rates deviate too far apart from each other, incentives will develop for private individuals to try to illegally arbitrage between these two rates. This may be one reason why the life expectancy of dual exchange rate systems is short relative to the more traditional exchange rate systems. Both Fleming (1974) and Lanyi (1975) discuss the difficulties with ensuring that the foreign exchange markets for current and capital account transactions are kept separate.

9 By plugging $(4.4)$ and $(4.5)$ into $(4.3)$, it can be shown that the welfare gain associated with an anticipated increase in the future terms of trade is

$$
\mathrm{d} \omega / \mathrm{d} \rho_{2}=\left\{\left[\partial c /\left.\partial \mathrm{f}\right|_{\omega=\bar{\omega}}+(1 /(1+i)) \mathrm{y}_{1} \partial \mathrm{m} / \partial \mathrm{f}\right]\left[(1-v(k)) \overline{\mathrm{x}}_{2} /(1+\mathrm{r})\right]\right\} / \Omega>0 .
$$

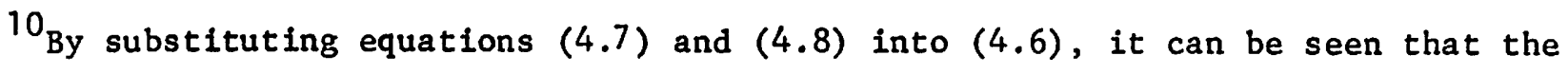
change in welfare following an increase in the government's target level for the capital account is 


$$
\begin{aligned}
\mathrm{d} w / \mathrm{d} c \mathrm{ca}=\left[[ ( \mathrm { r } - \mathrm { r } ^ { * } ) / ( 1 + \mathrm { r } ) ] \left[\partial \mathrm{c} /\left.\partial \mathrm{f}\right|_{\omega=\bar{\omega}}\right.\right. & \left.\left.+(1 /(1+\mathrm{i})) \mathrm{y}_{1} \partial \mathrm{m} / \partial f\right] / \Omega\right\} \\
& +\left[i * /(1+i) \mathrm{y}_{1} \partial \mathrm{m} / \partial \mathrm{f}\right] / \Omega \stackrel{?}{\gtrless} 0
\end{aligned}
$$

To understand intuitively why the sign of this expression is ambiguous, temporarily ignore the second term in brackets on the far right-hand side of the equation. It can now easily be seen that the sign of the welfare change depends on whether the domestic real interest rate, $r$, is higher or lower than the world real interest rate, $\mathrm{r}^{*}$. This makes sense. To see this, suppose that $r$ is greater than $r^{*}$. This would correspond to a situation where the target level for the capital account is below that which would exist in the uncontrolled economy. Here, domestic net external savings (borrowing) is being held above (below) its uncontrolled amount by keeping the domestic real interest rate above the world level. By relaxing the target savings level, domestic residents are made better off. Alternatively, when $r$ is less than $r *$ net external domestic savings is less than the uncontrolled level. By increasing the capital account target, and thus further reducing the level for net external domestic savings, agents are made worse off. Finally, the term on the far right-hand side of the equation represents the welfare gain agents realize through reduced transaction costs brought about by the increase in their real cash balances due to the rise in $f$ caused by the increase in $\overline{c a}$.

${ }^{11} \mathrm{Also}$, it is being assumed that the rest of the world is characterized by perfect competition in all markets. 
$1 \tau_{\text {This }}$ can be proved along the following line: Invert the first-order condition (2.4a) so as to achieve a solution for $m_{1}$, for given values of $y_{1}$, $i^{*}$ and $f$. Substitute this solution for $m_{1}$ into equation (3.8). Now, use the resulting expression to eliminate $b$ from equations (3.6) and (3.7). Finally, plug the modified versions of (3.6) and (3.7) into the first-order condition (2.3). It can now be seen this new version of (2.3) implicitly defines a solution for $f$ given a target level of the capital account, $\overline{c a}$, and the values for the other exogenous variables. But note one could just as easily think of (2.3) instead defining a solution for $\overline{c a}$ given values for $f$ and the other exogenous variables. In fact, it is easy to demonstrate that while holding the values of the exogenous variables constant, the relationship between $f$ and $\overline{c a}$ is univalent or one-to-one. Equation (4.7) illustrates that these two variables are positively related to each other.

${ }^{13}$ Since dual exchange rate systems and capital controls are essentially equivalent, the first comparative statics exercise tells one that an anticipated increase in future income with capital controls in place should lead to a rise in the domestic real interest rate,while the second indicates that a change in the level of quantitative restrictions which reduces the level of domestic net external savings will lower the real interest rate. Obstfeld (1984) also discusses the relationship between dual exchange rates and capital controls.

${ }^{14}$ Fleming (1974) and Lanyi (1975) provide intuitive discussions of the relative merits of a dual exchange rate system vis-à-vis capital controls. Both authors feel that allocative efficiency is greater under a dual exchange rate system. This is because in practice its incidence, unlike quantitative restrictions, is even across all capital flows. Fleming also claims that the administrative costs of a dual exchange rate system are likely to be lower than those of quantitative restrictions but Lanyi takes issue with this assertion. 
15 obviously, many other comparative statics experiments could be undertaken in this section. For instance, Obstfeld (1984) examines the impact of a devaluation in an economy with capital controls (or equivalently, a dual exchange rate system). This is a worthwhile exercise since, in practice, many devaluations are undertaken in situations where capital (and other) controls are present.

${ }^{16}$ It might be the case that a large country could benefit from the imposition of a dual exchange rate system if it could affect the world real interest rate, or the terms of trade at which it borrows or lends. This is, of course, directly related to the optimum tariff question in the standard trade literature. Alternatively, if there were some distortions in a "small" open economy then a dual exchange rate system might be preferable to free trade in assets. However, it is hard to believe that there wouldn't be alternative commercial policies, aimed at ameliorating these distortions, that would be preferable to a dual exchange rate system or capital controls. The general rule of thumb seems to be that one should use the commercial policy that most directly affects the source of the distortion. This type of issue has been extensively addressed by trade theorists--for example see Bhagwati (1981). ${ }^{17}$ As was shown (cf. (3.3) and (3.4)), the government may earn revenue through the operation of a dual exchange rate system. Thus, this exchange rate system could be operated so as to achieve certain revenue goals. In light of what has been said in footnote 8 , the government shouldn't get too greedy. Also, theoretically other forms of dual exchange rate systems are possible. For instance, the government could instead require that imports are done at a different exchange than all other international transactions which are done at some fixed exchange rate. The government could manipulate the exchange rate for imports so as to attain certain policy objectives such as a target level for imports or the trade balance. Essentially this form of dual exchange rate system would be equivalent to levying a tariff on imports. 
${ }^{18}$ Unlike most others, Flood and Marion (1982) explicitly model the domestic distortion present: it arises from imperfect (sub-optimal) labor contracting. Dual exchange rate systems are then evaluated on their ability to minimize the variance of actual (distorted) output around optimal output--the level of output that would exist in a world without the imperfect labor contracting. One would like to rank the welfare properties of a dual exchange rate system in ameliorating the effects of this distortion vis-à-vis other government policies which could be used to eliminate the distortion directly, such as a policy of state-contingent labor taxes and subsidies. Of course, a policy of state-contingent labor taxes and subsidies may not be in a government's opportunity set. 


\section{References}

Argy, Victor and Michael G. Porter, 1972, "The Forward Exchange Market and the Effects of Domestic and External Disturbances Under Alternative Exchange Rate Systems," I.M.F. Staff Papers 70, 502-528.

Aschauer, David and Jeremy Greenwood, 1983, "A Further Exploration in the Theory of Exchange Rate Regimes," Journal of Political Economy 91, 868-875.

Bhagwati, Jagdish N., 1965, "On the Equivalence of Tariffs and Quotas" in:

Robert E. Baldwin et al., eds., Trade, Growth, and the Balance of Payments

(Rand McNally and Co., Chicago), 53-67.

Bhagwati, Jagdish N., 1981, "The Generalized Theory of Distortions and Welfare" in: Jagdish N. Bhagwati, ed., International Trade: Selected Readings (The MIT Press, Cambridge), 171-189.

Dornbusch, Rudiger, 1976, "The Theory of Flexible Exchange Rate Regimes and Macroeconomic Policy," Scandinavian Journal of Economics 78, 255-275.

Fleming, J. Marcus, 1974, "Dual Exchange Markets and Other Remedies for Disruptive Capital Flows," I.M.F. Staff Papers 21, 1-27.

Flood, Robert P., 1978, "Exchange Rate Expectations in Dual Exchange Markets," Journal of International Economics 8, 65-77.

Flood, Robert P. and Nancy P. Marion, 1982, "The Transmission of Disturbances Under Alternative Exchange-Rate Regimes with Optimal Indexing," Quarterly Journal of Economics $96,41-66$.

Greenwood, Jeremy, 1983, "Expectations, the Exchange Rate and the Current Account," Journal of Monetary Economics 12, 543-569.

Greenwood, Jeremy, 1984, "Nontraded Goods, the Trade Balance and the Balance of Payments," Canadian Journal of Economics. 
Helpman, Elhanan, 1981, "An Exploration in the Theory of Exchange Rate Regimes," Journal of Political Economy $89,865-890$.

Lanyi, Anthony, 1975, "Separate Exchange Markets for Capital and Current Transactions," I.M.F. Staff Papers 22, 714-749.

Marion, Nancy, P., 1981, "Insulation Properties of a Two-tier Exchange Market in a Portfolio Balance Model," Economica 48, 61-70.

Obstfeld, Maurice, 1981, "Macroeconomic Policy, Exchange-Rate Dynamics, and Optimal Asset Accumulation," Journal of Political Economy 84, 1142-1161.

Obstfeld, Maurice, 1982, "The Capitalization of Income Streams and the Effects of OpenMarket Policy Under Fixed Exchange Rates," Journal of Monetary Economics 9, 87-98. Obstfeld, Maurice, 1984, "Capital Controls, The Dual Exchange Rate, and Devaluation," Working Paper No. 8423C, Centre for the Study of International Economic Relations, University of Western Ontario.

Persson, Torsten, 1984, "Real Transfers in Fixed Exchange Rate Systems and the International Adjustment Mechanism," Journal of Monetary Economics.

Sachs, Jeffrey, 1983, "Aspects of the Current Behavior of OECD Economies" in:

Emil M. Claassen and Pascal Salin, eds., Recent Issu es in the Theory of Flexible

Exchange Rates (North-Holland, Amsterdam), 101-122.

Stockman, Alan C., 1980, "A Theory of Exchange Rate Determination," Journal of Political Economy 88, 673-698.

Stockman, Alan C., 1983, "Real Exchange Rates Under Alternative Nominal Exchange Rate Systems," Journal of International Money and Finance 2, 147-166.

Svensson, Lars E. O. and Assaf Razin, 1983, "The Terms of Trade and the Current Account: The Harberger-Laursen-Metzler Effect," Journal of Political Economy 91, 97-125. 
1981

$8101 C$

$8102 C$

$8103 C$

$8104 \mathrm{C}$

$8105 C$

$3106 \mathrm{C}$

$8107 C$

8108C D gJ

8109C D S

$8110 \mathrm{C}$

$8111 \mathrm{C}$

$8201 C$

$8202 C$

$8203 C$

$8204 C$

$8205 C$

$8206 C$

$8207 \mathrm{C}$

$8208 C$

Markusen, James R. Factor Movements and Commodity Trade as Compliments: A survey of some Cases.

Conlon, R.M. Comparison of Australian and Canadian Manufacturing Industries: Some Empirical Evidence.

Conlon, R.M. The Incidence of Transport Cost and Tariff Protection: Some Australian Evidence.

Laidler, David. On the Case for Gradualism.

Wirick, Ronald G. Rational Expectations and Rational Stabilization Policy in an Open Economy

Mansur, Ahsan and John Whalley Numerical secification of Applied General Equilibrium Models: Estimation, Calibration, and Data.

Burgess, David F., Energy Prices, Capital Formation, and Potential GNP

Jimenez, E. and Douglas H Keare. Husing Consumption and Income in the Low Income Urban setting: Estimates from Panel Data in El Salvador

Whalley, John Labour Migration and the North-South Debate

Manning, Richard and John McMillan Government Expenditure and Comparative Advantage

Freid, Joel and Peter Hwitt Why Inflation Reduces Real Interest Rates

$\underline{1982}$

Manning, Richard and James R. Markusen Dynamic Non-Substitution and Long Run Production Possibilities

Feenstra, Robert and Ken Judd Tariffs, Technology Transfer, and Welfare

Ronald W. Jones, and Douglas D. Purvis: International Differences in Response to Common External Shocks: The Role of Purchasing Power Parity

James A Brander and Barbara J. Spencer: Industrial strategy with Committed Firms

Whalley, John, The North-South Debate and the Terms of Trade: An Applied General Equilibrium Approach

Roger Betancourt, Christopher Clague, Arvind Panagariya CAPI TAL UTI LIZATI ON IN GENERAL EQUTIIBRI UM

Mansur, Ahsan $H$ On the Estimation of Import and Export Demand Elasticities and Elasticity Pessimism.

Whalley, J. and Randy Wigle PRICE AND QUANTITY RIGIDITIES IN ADJUSTMENT TO TRADE POLICY CHANGES: ALTERNATIVE FORMULATIONS AND INITIAL CALCULATIONS

8209C DSU Jimenez, E. SQUATTING AND COMMUNITY ORGANIZATION IN DEVELOPING COUNTRIES: A CONCEPTUAL FRAMEWORK 
8210C Grossman, G.M. INTERNATIONAL COMPETITION AND THE UNIONIZED SECTOR

8211C LaIdler,D. FRIEDMAN AND SCHWARTZ ON MONETARY TRENDS - A REVIEW ARTICLE 8212C Imam, M.H. and Whalley, J. INCIDENCE ANALYSIS OF A SECTOR SPECIFIC MINIMUM
WAGE IN A TWO SECTOR HARRIS-TODARO MODEL. 8213C Markusen, J.R. and Melvin, J.R. THE GAINS FROM TRADE THEOREM WITH INCREASING
RETURNS TO SCALE. 8214C INDUSTRIAL ORGANIZATION AND THE GENERAL EQUILIBRIUM COSTS OF PROTECTION IN
SMALL OPEN ECONOMIES.

8215C Laidler, D. DID MACROECONOMICS NEED THE RATIONAL EXPECTATIONS REVOLUTION?

8216C Whalley, J. and Wigle, R. ARE DEVELOPED COUNTRY MULTILATERAL TARIFF REDUCTIONS NECESSARILY BENEFICIAL FOR THE U.S.?

8217C Bade, R. and Parkin, M. IS STERLING M3 THE RIGHT AGGREGATE?

8218C Kosch, B. FIXED PRICE EQUUILIBRIA IN OPEN ECONOMIES.

$\underline{1983}$

$8301 \mathrm{C}$ Kimbel1, L.J. and Harrison, G.W. ON THE SOLUTION OF GENERAL EQUILIBRIUM

8302C Melvin, J.R. A GENERAL EQUILIBRIUM ANALYSIS OF'.CANADIAN OIL POLICY. 8303C Markusen, J.R. and Svensson, L.E.O. TRADE IN GOODS AND FACTORS WITH
INTERNATIONAL DIFFERENCES IN TECHNOLOGY.

$8304 \mathrm{C}$ Mohammad, S. Whalley, J. RENT SEEKING IN INDIA: ITS COSTS AND POLICY
SIGNIFICANCE.

8305C DSU Jimenez, E. TENURE SECURITY AND URBAN SOUUATTING.

8306C Parkin, M. WHAT CAN MACROECONOMIC THEORY TELL US ABOUT THE WAY DEFICITS
SHOULD BE MEASURED.

8307C Parkin, M. THE INFLATION DEBATE: AN ATTEMPT TO CLEAR THE AIR.

8308C Wooton, I. LABOUR MIGRATION IN A MODEL OF NORTH-SOUTH TRADE.

8309C Deardorff, A.V. THE DIRECTIONS OF DEVELOPING COUNTRIES TRADE: EXAMPLES
FROM PURE THEORY. $8310 \mathrm{C}$ Manning, R. ADVANTAGEOUS REALLOCATIONS AND MULTIPLE EQUILIBRIA: RESULTS
FOR THE THREE-AGENT TRANSFER PROBLEM. 
8311C DSU Mohammad, S. and Whalley, J. CONTROLS AND THE INTERSECTORAL TERMS OF TRADE IN INDIA.

8312C Brecher, Richard A. and Choudhri, Ehsan U. NEW PRODUCTS AND THE FACTOR CONTENT OF INTERNATIONAL TRADE.

8313C Jones, R.W., Neary, J.P. and Ruane, F.P. TWO-WAY CAPITAL FLOWS: CROSSHAULING IN A MODEL OF FOREIGN INVESTMENT.

$8314 \mathrm{C}$ DSU Follain, J.R. Jr. and Jimenez, E. THE DEMAND FOR HOUSING CHARACTERISTICS IN DEVELOPING COUNTRIES.

8315C Shoven, J.B. and Whalley, J. APPLIED GENERAL EQUILIBRIUM MODELS OF TAXATION AND INTERNATIONAL TRADE.

8316C Boothe, Paul and Longworth David. SOME IRREGULAR REGULARITIES IN THE CANADIAN/U.S. EXCHANGE MARKET.

$8317 \mathrm{C}$ Hamilton, Bob and Whalley, John. BORDER TAX ADJUSTMENTS AND U.S. TRADE.

8318C Neary, J. Peter, and Schweinberger, Albert G. FACTOR CONTENT FUNCTIONS AND THE THEORY OF INTERNATIONAL TRADE.

8319C Veal1, Michael R. THE EXPENDITURE TAX AND PROGRESSIVITY.

$8320 \mathrm{C}$ Melvin, James R. DOMESTIC EXCHANGE, TRANSPORTATION COSTS AND INTERNATIONAL TRADE.

8321C Hamilton, Bob and Whalley, John. GEOGRAPHICALLY DISCRIMINATORY TRADE ARRANGEMENTS .

8322C Bale, Harvey Jr. INVESTMENT FRICTIONS AND OPPORTUNITIES IN BILATERAL U.S.-CANADIAN TRADE RELATIONS.

8323C Wonnacott, R.J. CANADA-U.S. ECONOMIC RELATIONS--A CANADIAN VIEW.

8324C Stern, Robert M. U.S.-CANADIAN TRADE AND INVESTMENT FRICTIONS: THE U.S. VIEW.

8325C Harrison, Glenn, H. and Kimbell, Larry, J. HOW ROBUST IS NUMERICAL GENERAL EQUILIBRIUM ANALYSIS?

8326C Wonnacott, R.J. THE TASK FORCE PROPOSAL ON AUTO CONTENT: WOULD THIS SIMPLY EXTEND THE AUTO PACT, OR PUT IT AT SERIOUS RISK?

8327C Bradford, James C. CANADIAN DEFENCE TRADE WITH THE U.S. Conklin, David. SUBSIDY PACTS.

Rugman, Alan M. THE BEHAVIOUR OF U.S. SUBSIDARIES IN CANADA: IMPLICATIONS FOR TRADE AND INVESTMENTS. 
8328C Boyer, Kenneth D. U.S.-CANADIAN TRANSPORTATION ISSUES.

8329C Bird, Richard M. and Brean, Donald J.S. CANADA-U.S. TAX RELATIONS: ISSUES AND PERSPECTIVES.

8330C Moroz, Andrew R. CANADA-UNITED STATES AUTOMOTIVE TRADE AND TRADE POLICY ISSUES.

8331C Grey, Rodney de C. and Curtis, John. INSTITUTIONAL ARRANGEMENTS FOR U.S.-CANADIAN NEGOTIATIONS. PART I: CANADA-U.S. TRADE AND ECONOMIC ISSUES: DO WE NEED A NEW INSTITUTION? PART II: INSTITUTIONAL ARRANGEMENTS FOR MANAGING THE CANADA-U.S. ECONOMIC RELATIONSHIP.

1984

$8401 \mathrm{C}$ Harrison, Glenn $\mathrm{W}$. and Manning, Richard. BEST APPROXIMATE AGGREGATION OF INPUT-OUTPUT SYSTEMS.

8402C Parkin, Michael. CORE INFLATION: A REVIEW ESSAY.

8403C Blomqvist, Ȧke, and McMahon, Gary. SIMULATING COMMERICAL POLICY IN A SMALL, OPEN DUAL ECONOMY WITH URBAN UNEMPLOYMENT: A GENERAL EQUILIBRIUM APPROACH.

8404C Wonnacott, Ronald. THE THEORY OF TRADE DISCRIMINATION: THE MIRROR IMAGE OF VINERIAN PREFERENCE THEORY?

8405C Whalley, John. IMPACTS OF A 50\% TARIFF REDUCTION IN AN EIGHT-REGION GLOBAL TRADE MODEL.

8406C Harrison, Glenn W. A GENERAL EQUILIBRIUM ANALYSIS OF TARIFT REDUCTIONS.

8407C Horstmann, Ignatius and Markusen, James R. STRATEGIC INVESTMENTS AND . THE DEVELOPMENT OF MULTINATIONALS.

8408C Gregory, Allan W. and McCurdy, Thomas H. TESTING THE UNBIASEDNESS HYPOTHESIS IN THE FORINARD FOREIGN EXCHANGE MARKET: A SPECIFICATION ANALYSIS.

8409C Jones, Ronald $\mathrm{C}$. and Kierzkowski, Henryk. NEIGHBORHOOD PRODUCTION STRUCTURES WITH APPLICATIONS TO THE THEORY OF INTERNATIONAL TRADE.

$8410 \mathrm{C}$ Weller, Paul and Yano, Makoto. THE ROLE OF FUTURES MARKETS IN INTERNATIONAL TRADE: A GENERAL EỌUILIBRIUM APPROACH.

8411C Brecher, Richard A, and Bhagwati, Jagdish N. VOLUNTARY EXPORT RESTRICTIONS VERSUS IMPORT RESTRICTIONS: A WELFARE-THEORETIC COMPARISON . 
8412C Ethier, Wilfred J. ILLEGAL IMMIGRATION.

8413C Eaton, Jonathon and Gene M. Grossman. OPTIMAL TRADE AND INDUSTRIAL POLICY UNDER OLIGOPOLY.

8414C Wooton, Ian. PREFERENTIAL TRADING AGREEMENTS - A 3xn MODEL.

8415C Parkin, Michael. DISCRIMINATING BETWEEN KEYNESIAN AND CLASSICAL THEORIES OF THE BUSINESS CXCLE: JAPAN 1967-1982

8416C Deardorff, Alan V. FIRless FIRwoes: HOW PREFERENCES CAN INTERFERE WITH THE THEOREMS OF INTERNATIONAL TRADE.

8417C Greenwood, Jeremy. NONTRADED GOODS, THE TRADE BALANCE, AND THE BALANCE OF PAYMENTS.

8418C Blomqvist, Ake and Sharif Mohammad. CONTROLS, CORRUPTION, AND COMPETITIVE RENT-SEEKING IN LDCs.

8419C Grossman, Herschel I. POLICY, RATIONAL EXPECTATIONS, AND POSITIVE ECONOMIC ANALYSIS.

8420C Garber, Peter M. and Robert G. King. DEEP STRUCTURAL EXCAVATION? A CRITIOQUE OF EULER EQUATION METHODS.

8421C Barro, Robert J. THE BEHAVIOR OF U.S. DEFICITS.

8422C Persson, Torsten and Lars E.0. Svensson. INTERNATIONAL BORROWING AND TIME-CONSISTENT FISCAL POLICY.

8423C Obstfeld Maurice. CAPITAL CONTROLS, THE DUAL EXCHANGE RATE, AND DEVALUATION.

8424C Kuhn, Peter. UNION PRODUCTIVITY EFFECTS AND ECONOMIC EFFICIENCY.

8425C Hamilton, Bob and John Whalley. TAX TREATMENT OF HOUSING IN A DYNAMIC SEOQUENCED GENERAL EỌUILIBRIUM MODEL.

8426C Hamilton, Bob, Sharif Mohammad, and John Whalley. RENT SEEKING AND THE NORTH-SOUTH TERMS OF TRADE.

8427C Adams, Charles and Jeremy Greenwood. DUAL EXCHANGE RATE SYSTEMS AND CAPITAL CONTROLS: AN INVESTIGATION. 